\title{
Prescription Pharmaceutical Market Goes Global for Consumers
}

I

t is no surprise that patients and payors are comparison-shopping for better prescription prices. It is also no surprise that they are looking to Mexico and Canada for lower prescription prices, since they go across the border to visit retail stores for lower prices on clothes, TVs, DVDs, food, and other consumer goods. Clearly, consumers benefit from the purchasing power of the U.S. dollar and from lower competitive prices. However, aside from the cost of drugs, there is something larger happening. The prescription drug market is going global for consumers.

Mexico and Canada are obvious places for consumers to comparison shop for prescription medications. But how much information is available to purchasers to make decisions about comparative costs in Canada or Mexico? A few years ago a client of mine requested a survey of the viability of sending employees to Canada or M exico to purchase prescription drugs. With the permission of the client, I'd like to share the general lessons from this survey regarding available prices, information, and possible limitations for decreasing prescription prices.

A market basket of commonly used medications was used for comparison purposes, and drug wholesalers in Mexico and Canada were contacted for pricing. The conditions of the survey were that these pharmaceuticals must be in dosage strengths commonly used in the United States, that the drugs be made by ethical U.S. manufacturers or manufacturers that operated plants that had been inspected by the Food and Drug Administration (FDA), and that for comparison purposes the drugs were available in quantities of 100 units per bottle. The market basket consisted of omeprazole, atorvastatin, simvastatin, lansoprazole, celecoxib, amlodipine, fluoxetine, pravastatin, diltiazem, and loratadine.

\section{- The Environment in Mexico}

Not surprisingly, drug manufacturers in Mexico, some of which are owned by U.S.branded manufacturers, make drugs for consumption in Mexico only. In order for pharmaceuticals to be imported into the United States, the Mexican plants must be registered with the FDA and each product must be filed with the FDA under "A New Drug Application" (ANDA). (Our request for a list of registered plants in Mexico required several months for a response from the FDA.) Citizens of the United States may have prescriptions filled in "any willing" retail pharmacy in Mexico, although the pharmacies may not carry medications in the prescribed quantities. Based on the exchange rate at the time, the market basket sold at an $89 \%$ discount to its price in the United States.

\section{The Environment in Canada}

Branded pharmaceuticals sold in Canada must be approved by the Canadian equivalent of the FDA, known as the Health Products and Food Branch (HPB). Pharmaceuticals manufactured in Canada cannot be shipped into the United States, but products manufactured in the United States can be shipped into Canada. Certain HPB regulatory requirements, however, still prevail (e.g., all products must be labeled in English and French). Pharmacists in Canada cannot legally dispense prescriptions written by a U.S. physician, unless approved by a Canadian physician. There are however, many anecdotes of pharmacists and physicians who have sub rosa facilitated the prescribing and dispensing of medications in Canada for U.S. patients. Based on the exchange rates at the time the market basket sold at a 59\% discount to its U.S. price.

\section{The Global Environment}

While Mexico and Canada are geographically close to the United States, the Internet provides a virtual world without borders. Drug distributors (e.g., GlobeXPharma.com and RxMarketplace.com) can supply pharmacies with medications. International drug manufacturers are increasingly visible in copying U.S. patents for branded pharmaceuticals. For example, Far-Manguinhos, a state-owned manufacturer in Brazil, is selling acquired immunodeficiency syndrome (AIDS) drugs for half the price charged by U.S. manufacturers.

Patent laws differ in every country, and in spite of W orld Trade Organization international patent protections, countries are placing their internal health care interests ahead of the patent requirements. For example, Brazilian companies are allowed by their government to manufacture a branded medication if a U.S. manufacturer is not making it in Brazil three years after the patent is issued.

The overwhelming issue is that local interests are beating out commercial interests not just in drugs, but also in software, movies, music, and other commodities. Manufacturing and distribution is global so that international drug companies may subcontract-manufacture or they may manufacture their own products as well. The result is an expanding international market for patented and off-patent products. ${ }^{1}$

Consumers can now embrace the international market, because they have price information and access to competitive prices over the Internet. The next step should be a free flow of marketing information about individual medications and comparative features and options of therapeutically similar medications. Information that manufacturers have traditionally offered only to providers (e.g., indications, frequency of dosing) should soon be available to consumers.

The global train has left the station. Between the free flow of information, consumerism, and globalism, the health care world will never be the same.

\section{Reference}

1. Jordon M, Brazil may flout trade laws to keep AIDS drugs free for patients. Wall Street Journal, February 12, 2001, B1, B4. 